\title{
Valley to Valley: The Biological Connection between Prehispanic Residents of Cochabamba, Bolivia, and Azapa, Chile
}

\author{
Héctor H. Varela ${ }^{1 \#}$, José A. Cocilovo ${ }^{1}$, Tyler G. O’Brien ${ }^{2}$ \\ ${ }^{1}$ Departamento de Ciencias Naturales, Facultad de Ciencias Exactas, Físico-Química y Naturales, Universidad \\ Nacional de Río Cuarto, Río Cuarto, Argentina \\ ${ }^{2}$ Department of Sociology, Anthropology and Criminology, University of Northern Iowa, Baker 356, \\ Cedar Falls, Iowa \\ Email: "hvarela@exa.unrc.edu.ar
}

Received July $11^{\text {th }}$, 2013; revised August $14^{\text {th }}$, 2013; accepted September $12^{\text {th }}, 2013$

Copyright (c 2013 Héctor H. Varela et al. This is an open access article distributed under the Creative Commons Attribution License, which permits unrestricted use, distribution, and reproduction in any medium, provided the original work is properly cited.

\begin{abstract}
One of the most interesting problems facing the interpretation of south central Andean prehistory is to decipher the genetic relationships among ancient groups that inhabited this region. This study evaluates the biological relationships between the ancient inhabitants of the coast and interior valleys of the Azapa region in northern Chile and the Cochabamba valleys of Bolivia, with reference to highland Tiwanaku groups. Craniometric data $(\mathrm{N}=299)$ were statistically evaluated to compute group means using Mahalanobis $\left(\mathrm{D}^{2}\right)$ values. Results demonstrate that there is a notable difference between coastal and interior valley populations of the Azapa region; whereas a close biological association exists between groups from the Cochabamba valleys and the interior Azapa valleys, especially for those associated with the Formative and Tiwanaku Periods.
\end{abstract}

Keywords: Craniometrics; Arica; Tiwanaku; South Central Andes

\section{Introduction}

The study of Tiwanaku expansion and influence in other regions of the south central Andes is of great interest. Its important cultural development and bicultural impact are seen most dramatically in places like southern Peru, northern Chile, parts of Bolivia and northwest Argentina. In general, different investigators agree that the imperial expansion into peripheral areas like the Cochabamba valleys of Bolivia, Moquegua in Peru or northern Chile was possible due to varied resource acquisition strategies, such as trade and direct exploitations (Berenguer \& Dauelsberg, 1989; Kolata, 1993; Uribe \& Agüero, 2001).

Some authors consider that the Azapa Valley in northern Chile was one of the first places colonized by a Tiwanaku culture named Cabuza (500 - 1225 A.D.) that subsisted alongside the local culture during the Formative or Alto Ramirez phase (Berenguer \& Dauelsberg, 1989; Berenguer, 2000). While other researchers like Uribe (1999) and Uribe and Agüero (2001) propose that the Tiwanaku-Azapa connection was less direct and the relationship with the altiplano was maintained more directly through Moquegua in Peru.

For the Middle Period in Azapa (500 - 1290 A.D.), two ma-

\footnotetext{
*This project was supported financially by grants from Consejo Nacional de Investigaciones Científicas y Técnicas (PIP 2405/08), Secretaría de Ciencia y Técnica-Universidad Nacional de Río Cuarto, Agencia Nacional de Promoción Científica y Técnica (02210/07) of Argentina; a National Science Foundation doctoral dissertation improvement grant (SBR 9903631), and various faculty fellowships from the University of Northern Iowa, Cedar Falls.

\#Corresponding author.
}

jor ceramic traditions have been identified one from the altiplano and another from the western valleys (Espoueys et al., ms.; Uribe, 1995, 1999, 2004). These represent non-sequential phases of cultural historical development. Based on these results, Agüero (2000) observes that in the Azapa Valley two types of textile styles exist that, coincidentally relate quite closely to the ceramic styles of the same areas. One textile type is related more to styles of the Late Formative Period in the Cochabamba valleys of Bolivia (e.g., Mojocoya and Omereque) and Middle Period of the southern altiplano lakeside region. The second textile type maintains stylistic affiliation with cultural groups from southern Peru.

Many works have examined settlement patterns, population structure, biological relationships, and evolution of human groups that have inhabited the south central Andes (Cocilovo, 1981; Rothhammer et al., 1981, 1982, 1983, 1984; Cocilovo \& Di Rienzo, 1984-85; Rothhammer \& Silva, 1989; Baffi \& Cocilovo, 1989-90; Cocilovo \& Rothhammer, 1990; Dittmar, 1996; Blom et al., 1998; Cocilovo et al., 1999a, 1999b, 2001, 2004; O’Brien, 2003; Varela et al., 1999, 2004a, 2004b; Varela \& Cocilovo, 2011; among others). The relationship network is extensive and complicated. For example, it has been demonstrated that morphological differences exist between the Azapa coastal and valley groups of 3500 B.C. and 1470 A.D. In particular, during the Alto Ramirez cultural phase of the Late Formative Period (500 B.C. - 630 A.D.) a high rate of gene flow into the Azapa valley is noted (Varela \& Cocilovo, 2002). This occurred most likely as a consequence of multiple migrations over time. This case will be examined in more detail later in this paper. 
However, in other cases, like in Peru or Bolivia, it has been shown that groups from highland Tiwanaku have a morphological similarity with those in Moquegua, Peru (Blom et al., 1998). Lozada et al. (2004) found that coastal groups of Chiribaya in the Osmore Valley Basin (Southern Peru) are biologically similar from formative coastal population of Roca Verde, while they did observe differences among Chiribaya and Chen Chen Tiwanaku population in Moquegua (medium Osmore valley). These results suggest a coastal origin of the Chiribaya. While in the Cochabamba valleys of eastern Bolivia there was only a minimal, if any, biological influence from the highlands (O’Brien, 2003). In fact, the ancient inhabitants of the Cochabamba valleys are more biologically related to groups for northern Chile and northwest Argentina than the two latter groups are to each other (Varela et al., 2008). Cochabamba is actually more phenotypically similar to northwest Argentina groups. Of those from northern Chile, Cochabamba is more related to groups from sites like Arica, than those from places like Atacama or Pisagua.

The objective of this paper is to evaluate the degree of morphological similarity of Formative and Tiwanaku period groups from the Cochabamba valleys of Eastern Bolivia with those Formative and Middle period groups that resided in the coastal and valley regions of Arica, Chile. Results will demonstrate important information related to the origins of the Azapa valley groups in Chile as well as the degree of genetic exchange that existed between Arica and Cochabamba. Additionally, they will shine light on the archaeological question regarding the existence of area-specific ceramic and textile traditions, and an interpretation of non-sequential cultural historical development in Arica (Espoueys et al., ms.; Uribe, 1995, 1999; Agüero, 2000).

\section{Materials and Methods}

Three series of crania were utilized in this study: two are from coastal and valley sites in the Azapa region (Arica) in northern Chile and one from various sites in the Cochabamba valleys of eastern Bolivia (see Figure 1). The Chilean crania were examined at the Museo de Arqueología San Miguel de Azapa in Arica while the Bolivian crania were studied at the
Museo Arqueológico in Cochabamba. As detailed in Table 1, the entire study simple consisted of a total of 299 adult crania (149 males and 150 females), non-deformed and artificially deformed (tabular and circular styles), corresponding to the Late Archaic (Vera, 1981; Allison et al., 1984; Focacci \& Chacón, 1989; Standen, 1991), Formative (Focacci, 1974; Rivera, 1977, 1987, 1991; Espoueys et al., ms.), Tiwanaku (Espoueys et al., ms.), Late Intermediate and Late periods (Hidalgo \& Focacci, 1986) for the Azapa region and for the Formative and Tiwanaku periods for the Cochabamba valleys (O’Brien, 2003). Sex and age at death determination was based on methods developed by Acsádi and Nemeskéri (1970), Bass (1981), Buikstra and Ubelaker (1994), Molnar (1971), and Lovejoy (1985). Classification of artificial deformation and type was according to Dembo and Imbelloni (1938).

The craniometric dimensions recorded were: maximum cranial length (MAXCL), maximum cranial breadth (MAXCB), maximum cranial height (BABH), upper facial breadth (UPFB), upper facial height (UPFH), bizygomatic breadth (BIZYGB), orbital height (ORH), basion-prosthion length (BAPRL), cranial base length (CRNBSL) and nasal breadth (NZBR).

To analyze the relationships between the groups without the influence of another factor of variation, the variation due to sex, age and artificial deformation was extracted from the above variables by linear regression (Seber, 1984). The samples that correspond to the Late Archaic period for the Azapa region and the Formative period for Cochabamba represent random subsets of the total number of individuals available in the two groups, since both had a large size relative with the rest of the periods.

In order to evaluate the biological relationships between the Cochabamba and Arica groups, we compared the Formative and Tiwanaku period groups from Cochabamba to those of the Late Archaic, Early Intermediate, Middle and Late Intermediate, and Late periods of the coast and valley sites of the Azapa region. To achieve this we employed multivariate analysis of variance, canonical discriminant analysis and Mahalanobis' D2 distance statistic (Rao, 1952; Seber, 1984). To display the results graphically a cluster analysis was performed (Kaufman \& Rousseeuw, 1990) using the UPGMA method and the previously calculated distances.

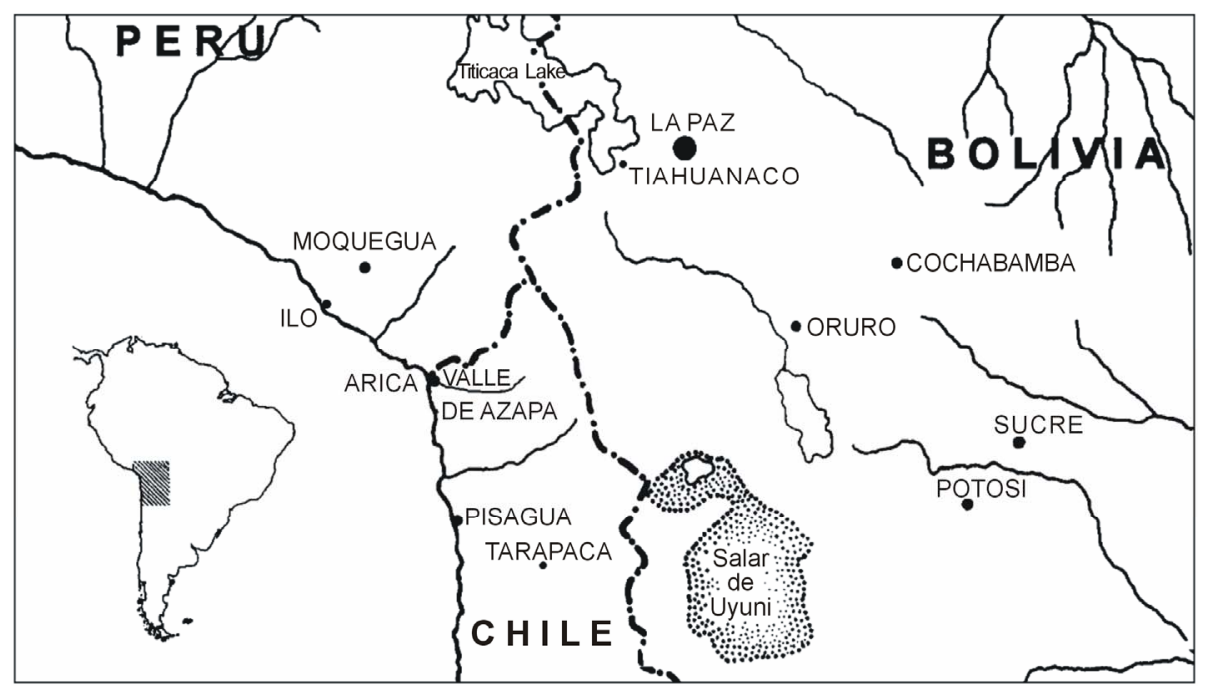

Figure 1.

Map of South Central Andean region with study sample locations and relevant geographic places. 
Table 1.

Study samples by group name, size, site, cultural phase and chronology.

\begin{tabular}{|c|c|c|c|c|c|}
\hline Region & Group Name (Code) & $\mathrm{N}$ & Site & Cultural phase & Chronology \\
\hline \multirow[t]{2}{*}{ Cochabamba } & Tiwanaku (CO-TI) & 45 & $\begin{array}{l}\text { Mojocoya, Incallacta, Omereque, } \\
\text { Pojo Amano, }\end{array}$ & $\begin{array}{l}\text { Omereque } \\
\text { Mojocoya }\end{array}$ & 500 - 1100 A.D. \\
\hline & Formative (CO-FO) & 11 & $\begin{array}{l}\text { Vinto/Quillacollo, Cliza-Chullpapata, } \\
\text { Guillen }\end{array}$ & $\begin{array}{l}\text { Mojocoya } \\
\text { Tupuraya }\end{array}$ & 0 - 500 A.D. \\
\hline \multirow[t]{6}{*}{ Azapa } & $\begin{array}{l}\text { Late and late intermediate, coast } \\
\text { (AZ-LA-C) }\end{array}$ & 46 & PLM4, PLM3, CAM8, CHLL5 & $\begin{array}{l}\text { Inka/Hispanic, } \\
\text { Gentilar, San Miguel }\end{array}$ & $\begin{array}{l}>1470 \text { A.D. } \\
1100-1470 \text { A.D. }\end{array}$ \\
\hline & Late intermediate, valley (AZ-LA-V) & 56 & $\begin{array}{l}\text { AZ71, AZ105, AZ79, AZ8, AZ82, } \\
\text { LL12 }\end{array}$ & San Miguel, Gentilar & 990 - 1145 A.D. \\
\hline & $\begin{array}{l}\text { Middle or tiwanaku, valley } \\
\text { (AZ-TI-V) }\end{array}$ & 12 & AZ3, AZ103, AZ13 & Cabuza, Maytas & 500 - 1270 A.D. \\
\hline & $\begin{array}{l}\text { Early intermediate or formative, coast } \\
\text { (AZ-FO-C) }\end{array}$ & 47 & PLM 7 & El Laucho & 530 B.C. \\
\hline & $\begin{array}{l}\text { Early intermediate or formative, } \\
\text { valley (AZ-FO-V) }\end{array}$ & 38 & AZ 14, AZ 70, AZ 115, AZ22 & Alto Ramírez & 500 B.C. - A.D 630 \\
\hline & $\begin{array}{l}\text { Late archaic, coast } \\
\text { (AZ-AR-C) }\end{array}$ & 44 & Morro Uhle, Morro 1, Morro 1-6 & Chinchorro & 3500 - 1700 B.C. \\
\hline
\end{tabular}

\section{Results}

A significant difference exists (Wilks' Lambda $=0.67726, \mathrm{~F}$ $(20,574)=6.1743, p<0.00001)$ when comparing the three groups: the Cochabamba sample (CO) with the coastal group from Azapa (AZ-C) and the one from the valley of Azapa (AZV). In Table 2 one can see that the distance between $\mathrm{CO}$ and $\mathrm{AZ}-\mathrm{V}$ is 0.537 , or in other words 2.6 times smaller than the distance between CO and AZ-C (1.387), and 3.4 times smaller than the distance that exists between AZ-C and AZ-V (1.812). Of the two canonical coordinates obtained through discriminant analysis, only the first of them exhibits statistical significance between the groups, explaining $87 \%$ of the total variation; while the second accounts for the remaining $13 \%$.

The reclassification of the observations by discriminant functions, using an equal a priori classification probability for the three groups, shows that the percentage of correct assignment was $66.7 \%$ (AZ-C), 53.8\% (AZ-V) and 41.1\% (CO) (see Table 3). In other words, $34.3 \%$ of the observations of the first group (AZ-C) were reclassified as AZ-V (18.2\%) or as CO (16.1\%); $46.2 \%$ of the second group (AZ-V) were reclassified as AZ-C (23.6\%) or as CO (22.6\%), and finally $58.9 \%$ of the third group (CO) were reclassified as AZ-C (23.2\%) or as AZ-V (35.7\%).

When we studied the relationship between samples of different periods of the coast and the valley of Azapa and Cochabamba valleys (see Table 1), the results also showed morphological differences among the eight groups compared (Wilks Lambda: 0.47508, F (70.1651) $=3.2113, p<0.0000)$. As seen in Table 4, the smallest Mahalanobis $\left(\mathrm{D}^{2}\right)$ distances between any of the three groups occurred between the Cochabamba Formative Period group (CO-FO) and the Azapa valley Early Intermediate group (AZ-FO-V) with a value of 0.831 . The other smallest value occurred between the Cochabamba Tiwanaku period group and the Azapa valley Early Intermediate group (AZ-FO-V) with a value of 0.637 . Neither value demonstrated statistical significance. In fact, looking at all the Mahalanobis $\left(D^{2}\right)$ distances in Table 4, it is evident that a closer affinity exists between either of the two period Cochabamba groups with the Azapa valley groups from any period than Cochabamba has with the Azapa coast groups.
Table 2.

Mahalanobis distances $\left(\mathrm{D}^{2}\right)$ between Cochabamba and the coastal and valley sites of Azapa*.

\begin{tabular}{cccc}
\hline & AZ-C & AZ-V & CO \\
\hline AZ-C & ------ & 1.812 & 1.387 \\
AZ-V & 0.000 & ------ & 0.537 \\
CO & 0.000 & 0.044 & ----- \\
\hline
\end{tabular}

Note: *Mahalanobis values $\left(\mathrm{D}^{2}\right)$ are presented in the upper half of the matrix and probabilities in the lower half. $\mathrm{F}=10$ and 287 d.f.

Table 3.

Number and percentage of cases correctly classified in each group by the discriminant functions*.

\begin{tabular}{ccccc}
\hline & AZ-C & AZ-V & CO & Total \\
\hline AZ-C & $90(65.7)$ & $25(18.2)$ & $22(16.1)$ & 137 \\
AZ-V & $25(23.6)$ & $57(53.8)$ & $24(22.6)$ & 106 \\
CO & $13(23.2)$ & $20(35.7)$ & $23(41.1)$ & 56 \\
Total & 128 & 102 & 69 & 299 \\
\hline
\end{tabular}

Note: ${ }^{*}$ Number in parentheses is the proportion.

The difference between all eight samples analyzed can be demonstrated by the first three discriminant canonical variables which account for $86 \%$ of the total between-groups variation (55\%, $19 \%$ and $12 \%$, respectively). The remaining $13 \%$ is explained by the fourth canonical variable.

The distribution of the Cochabamba and Azapa samples from various temporal periods, based on the centroids of the first and second canonical variables, is displayed in Figure 2. On the right side of the plot the Cochabamba valley Formative (COFO) and Tiwanaku period (CO-TI) groups are more closely relationship with the Azapa valley groups, in particular the one from the Early Intermediate (AZ-FO-V). In addition, groups Azapa coast differ from the rest of the samples, being located in the lower portion of the graph to the left.

In order to visually display inter-group biological similarity, Mahalanobis $\left(\mathrm{D}^{2}\right)$ distances between all of the groups are plotted in a dendrogram in Figure 3. In this manner, two major 
Table 4.

Mahalanobis $\left(\mathrm{D}^{2}\right)$ distances between Cochabamba and Azapa groups*.

\begin{tabular}{cccccccccc}
\hline & \multicolumn{3}{c}{ Azapa-Coast } & \multicolumn{3}{c}{ Azapa-Valley } & \multicolumn{3}{c}{ Cochabamba } \\
\cline { 2 - 9 } & AZ-AR-C & AZ-FO-C & AZ-LA-C & AZ-FO-V & AZ-TI-V & AZ-LA-V & CO-FO & CO-TI \\
\hline AZ-AR-C & ------ & 1.040 & 0.706 & 1.591 & 2.593 & 2.662 & 2.283 & 1.056 \\
AZ-FO-C & 0.013 & ------ & 1.431 & 2.775 & 2.181 & 4.175 & 3.904 & 1.993 \\
AZ-LA-C & 0.126 & 0.001 & ------ & 1.831 & 3.312 & 2.560 & 3.115 & 1.625 \\
AZ-FO-V & 0.001 & 0.000 & 0.000 & ------ & 1.901 & 1.321 & 0.831 & 0.637 \\
AZ-TI-V & 0.011 & 0.031 & 0.001 & 0.085 & ------ & 2.998 & 2.708 & 1.524 \\
AZ-LA-V & 0.000 & 0.000 & 0.000 & 0.002 & 0.002 & ---- & 1.705 & 1.339 \\
CO-FO & 0.039 & 0.000 & 0.004 & 0.737 & 0.137 & 0.132 & ------ & 0.813 \\
CO-TI & 0.014 & 0.000 & 0.000 & 0.246 & 0.180 & 0.001 & 0.727 & ------ \\
\hline
\end{tabular}

Note: ${ }^{*}$ Mahalanobis values for $\mathrm{D}^{2}$ are presented in the upper half of the matrix and probabilities in the lower half. $\mathrm{F}=10$ and 282 d.f. Group codes are in Table $\mathbf{1}$.

clusters stand out: one constituted by all of the Azapa coastal samples, and the other constructed of into two smaller clusters, one being the Cochabamba groups from both temporal periods (CO-FO, CO-TI) with the Azapa valley Early Intermediate (AZ-FO-V) along with a another being the Azapa valley groups from the Middle and Late periods (AZ-TI-V and AZ-LA-V).

\section{Discussion}

The cross-temporal interpretation of the strong phenotypic and genotypic relationships that exist between some of the groups studied, when applying a population genetics perspective, implies an elevated level of migration between regions, that is to say a high level of gene flow. The apparent observed relationship among the Azapa valley and Cochabamba groups (see Table 2) would indicate a close common origin and a high level of genetic interaction between them in contrast to one with the inhabitants of the Azapa coast. More specifically, the biodistances derived from the craniometric analysis of groups from different regions and temporal periods (see Table $\mathbf{4}$ and Figures 2 and 3) suggest that those ancient inhabitants who resided in the Cochabamba valleys (i.e., Tupuraya, Mojocoya and Omereque) during the Formative (0 - 500 A.D.) and Tiwanaku (500 - 1100 A.D.) periods are strongly related to those ancient inhabitants of the Azapa valley, particularly to those of the Formative period (500 B.C. - 630 A.D.) of the Alto Ramirez culture, and with the Cabuza and Maytas cultures of the Tiwanaku period (500 - 1270 A.D.). In other words, the early migrants who traveled west from the Cochabamba valleys and who settled in the Azapa valley, during the Early Intermediate or Formative periods, eventually interbred with the local population, hence increasing the genetic variability (Varela \& Cocilovo, 2002; Varela et al., 2006).

According to O’Brien (2003), biological distances derived from an analysis of both metric and non-metric cranial traits reveals morphological continuity among ancient groups of the Cochabamba valleys with a notable discontinuity between them and residents of highland sites of Tiwanaku and the Katari basin. Additionally, Blom and colleagues (1998) have shown, through an analysis of non-metric traits, that Tiwanaku period inhabitants of the Moquegua valley are more closely affiliated, biologically, with highland residents of Tiwanaku and the Katari basin than earlier groups of the valley. Furthermore, utilizing a similar methodology, Lozada and colleagues (2004)

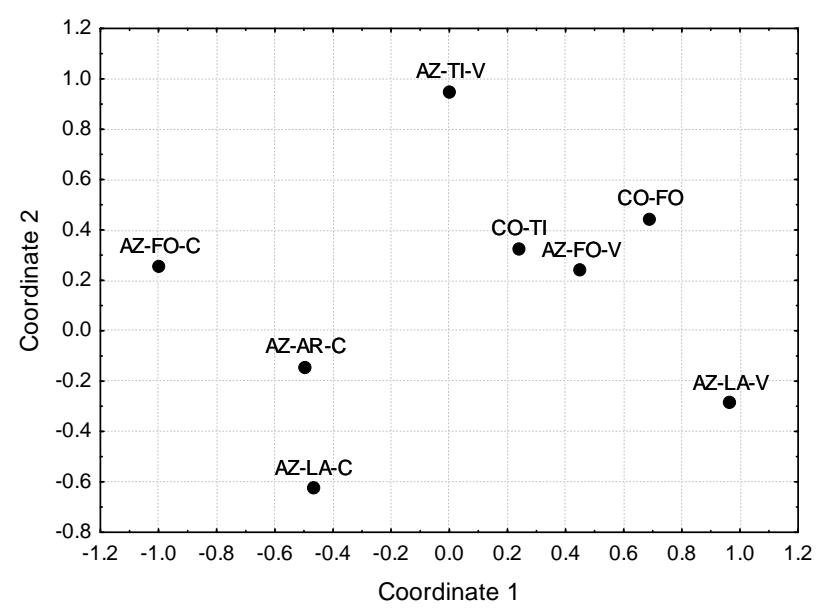

Figure 2.

Distribution of the Cochabamba and Azapa samples by cultural period based on the first (55\%) and second (19\%) canonical coordinates.

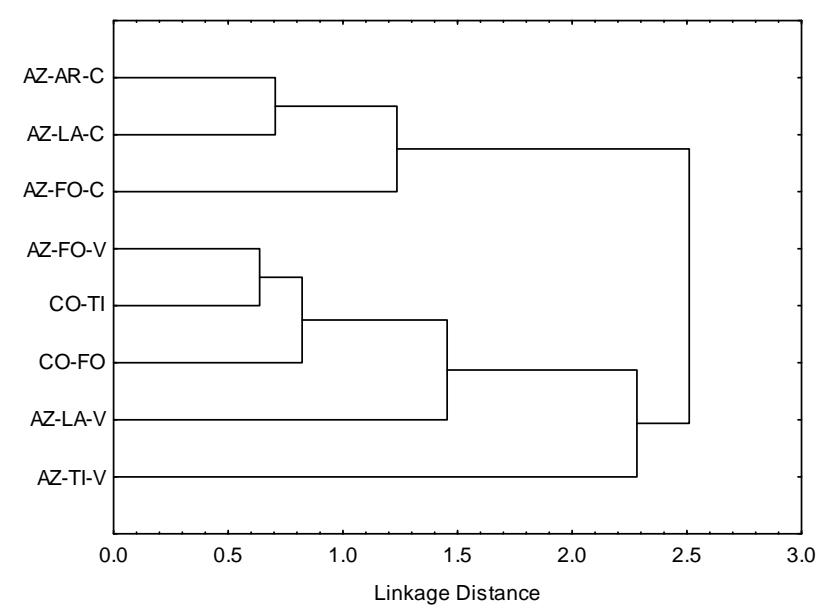

Figure 3.

Dendrogram representing the Mahalanobis distances $\left(D^{2}\right)$ of the Cochabamba and Azapa samples using the UPGMA method.

examined Chiribaya groups (750 - 1100 A.D.) from the Osmore coast of southern Peru. Those groups were found to be more biologically related with coastal residents from earlier periods 
than they are with Tiwanaku residents of Chen Chen in Moquegua. Agreeing with this, in Azapa we demonstrated that coastal populations are more related to each other than with respect to interior valleys groups (Figure 3).

There is very little doubt over the amount of hegemonic power Tiwanaku had in the area. Some archaeologists consider that the Tiwanaku colonists, called Cabuza, settled in the Azapa valley region and lived alongside, for some time, the Formative period group known as Alto Ramirez (Berenguer \& Dauelsberg, 1989; Berenguer, 2000). While others argue that localities like: Azapa in northern Chile, Ilo on the south coast of Peru, or Omereque and Mizque in the eastern valleys of Bolivia exhibit a stronger relationship with those of Moquegua and Cochabamba, respectively, than with groups from the Tiwanaku highlands (Uribe \& Agüero, 2001). In fact, our results support Agüero's (2000) contention that the textile tradition that existed during the Late Formative and Middle periods in Azapa, and the ones from the Cochabamba valley region (Omereque \& Mojocoya) are closely associated. Thus, the biological variability that existed in Azapa supports the proposition of non-sequential cultural historical development for the region (Espoueys et al., ms.; Uribe, 1995, 1999, 2004).

The differences observed between the coastal and valley groups of the Azapa region during the Late Intermediate and Late periods corroborate the conclusions drawn by Varela and Cocilovo (2002). In other words, the results support the ethnohistorical hypothesis that there was a marked social and economic difference between the inhabitants of the coast who specialized in obtaining maritime resources and those of the interior valleys who were more agricultural based (Rostworowsky, 1981, 1986; Schiappacasse \& Niemeyer, 1989).

In conclusion, our study shows that the cultural change observed during the Early Intermediate Period of the Azapa Valley was accompanied by an increase in biological variability due to gene flow over time from other regions, in particular those from the eastern valleys of Cochabamba, Bolivia. The established results from this work and those of previous studies should be interpreted under a general model of economic, cultural and biological exchange between both regions and smaller areas across the south central Andes and across time. The direction and intensity of this network of interaction and exchange varies across time and space. In this respect, the movement of materials and ideologies did not necessarily have the same impact as did the amount of gene flow from the incoming populations to the region. That is to say, the influence of biological exchange could be equal, more or less to the influence of cultural or economic factors.

\section{Acknowledgements}

The authors would like to acknowledge the assistance, support and encouragement from a number of people who helped with this manuscript in various aspects of the project in general: Ingrid Carlstein, and the faculty and staff at the various museums and institutions that curate the collections of crania utilized in this study, like the Museo Arqueológico in Cochabamba, Bolivia, the Museo Nacional de Historia Natural in Santiago, Chile, and the Museo de Arqueología San Miguel de Azapa in Arica, Chile.

\section{REFERENCES}

Acsádi, G., \& Nemeskéri, J. (1970). History of human life span and mortality. Budapest: Akadémiai Kiadó.

Agüero, C. (2000). Las tradiciones de Tierras Altas y de Valles Occidentales en la textilería arqueológica del Valle de Azapa. Chungara, 32, 217-225.

Allison, M., Focacci, G., Arriaza, B., Standen, V., Rivera, M., \& Lowenstein, J. (1984). Chinchorro. Momias de preparación complicada: Métodos de momificación. Chungara, 13, 155-174.

Baffi, I., \& Cocilovo, J. A. (1989-90). La población prehispánica tardía del sector septentrional del Valle Calchaquí. RUNA, 19, 11-26.

Bass, W. M. (1981). Human osteology: A laboratory and field manual of the human skeleton. Springfield, MO: University of Missouri Press.

Berenguer, J. (2000). Tiwanaku: Señores del Lago Sagrado. Santiago, Chile: Museo Chileno de Arte Precolombino.

Berenguer, J., \& Dauelsberg, P. (1989). El Norte Grande en la órbita de Tiwanaku (400 a 1.200 d.C.). In: J. Hidalgo, V. Schiappacasse, H. Niemeyer, C. Aldunate, \& I. Solimano (Eds.), Culturas de Chile. Prehistoria. Desde sus orígenes hasta los albores de la conquista (pp. 129-180). Santiago, Chile: Editorial Andrés Bello.

Blom, D. E., Hallgrímsson, B., Keng, L., Lozada, C. M. C., \& Buikstra, J. E. (1998). Tiwanaku "colonization": Bioarchaeological implications for migration in the Moquegua valley, Peru. World Arch, 30, 238-261.

Buikstra, J. E., \& Ubelaker, D. (1994). Standards for data collection from human skeletal remains. Research series no. 44. Fayetteville, Arkansas: Arkansas archeological survey research series n ${ }^{\circ} 44$.

Cocilovo, J. A. (1981). Estudio sobre discriminación y clasificación de poblaciones prehispánicas del N. O. Argentino. Publicación Ocasional, Mus Nac Hist Nat, Chile, 36, 1-59.

Cocilovo, J. A., \& Di Rienzo, J. A. (1984-85). Un modelo biológico para el estudio del poblamiento prehispánico del territorio argentino. Correlación fenético-espacial. Relaciones, Bs. As., 16, 119-135.

Cocilovo, J. A., Quevedo, S., Varela. H. H., Valdano, S., \& Castro, M. (1999a). Biología del grupo prehistórico de Pisagua, costa norte de Chile. Estudios Atacameños, Chile, 17, 207-235.

Cocilovo, J. A., \& Rothhammer, F. (1990). Paleopopulation biology of the southern Andes: Craniofacial chronological and geographical differentiation. Homo, 41, 16-31.

Cocilovo, J. A., Varela, H. H., Baffi. E. I., \& Valdano, S. G. (1999b). Estructura y composición de la población antigua de la Quebrada de Humahuaca. Análisis multivariado. Revista Argentina Antropología Biológica, 2, 7-26.

Cocilovo, J. A., Varela, H. H., Espoueys, O., \& Standen, V. (2001). El proceso microevolutivo de la población nativa antigua de Arica. Chungara, 33, 13-20.

Cocilovo, J. A., Varela, H. H., Quevedo, S., Standen, V., \& Costa-Junqueira, M. A. (2004). La diferenciación geográfica de la población humana arcaica de la costa norte de Chile (5000-3000 AP) a partir del análisis estadístico de rasgos métricos y no métricos del cráneo. Revista Chilena Historia Natatural, 77, 679-693.

Dembo, A., \& Imbelloni, J. (1938). Deformaciones intencionales del cuerpo humano. Humanior, Sección A 3. Buenos Aires: Imprenta Luis L. Gotelli.

Dittmar, M. (1996). A study of the face structure of highland and lowland populations in prehispanic South America. Microvariation and population relationships. Coll Antropol, 20, 95-110.

Espoueys, E., Uribe, M., Roman, A., \& Deza, A. (manuscript) Nuevos fechados por termoluminiscencia para la cerámica del Período Medio del Valle de Azapa (primera parte). FONDECYT 193-0202. Santiago.

Focacci, G. (1974). Excavaciones en el cementerio Playa Miller 7, Arica. Chungara, 3, 23-74.

Focacci, G., \& Chacón, S. (1989). Excavaciones arqueológicas en los faldeos del Morro de Arica, sitios 1/6 y 2/2. Chungara, 22, 15-62.

Hidalgo, J., \& Focacci, G. (1986). Multietnicidad en Arica. S.XVI. Evidencias etnohistóricas y arqueológicas. Chungara, 16-17, 137-147.

Kaufman, L., \& Rousseeuw, P. (1990). Finding groups in data: An introduction to cluster analysis. New York: John Wiley \& Sons.

Kolata, A. L. (1993). The tiwanaku: Portrait of an andean civilization. Cambridge, MA: Blackwell.

Lovejoy, C. O. (1985). Dental wear in the Libben population: Its functional pattern and role in the determination of adult skeletal age and 
death. American Journal of Physical Anthropology, 68, 47-56.

Molnar, S. (1971). Human tooth wear: tooth function and cultural variability. American Journal of Physical Anthropology, 34, 175-189.

Lozada, M. C., Blom, D. E., Hallgrímsson, B., \& Buikstra, J. E. (2004). Las relaciones biológicas y culturales entre Tiwanaku y Chiribaya en la cuenca del Osmore, extremo sur de Perú. In M. A. Rivera, \& A. L. Kolata (Eds.), Tiwanaku: Aproximaciones a sus contextos históricos y sociales (pp. 179-190). Santiago: Editorial Universidad Bolivariana.

O’Brien, T. G. (2003). Cranial microvariation in prehistoric south central andean populations: An assessment of morphology in the Cochabamba collection, Bolivia. Ph.D. Thesis, State University of New York: Binghamton University.

Rao, C. (1952). Advanced statistical methods in biometrics research. New York: Wiley.

Rivera, M. (1977). Prehistoric chronology of northern Chile. Ph.D. Thesis, Madison: University of Wisconsin.

Rivera, M. (1987). Tres fechados radiométricos de Pampa de Alto Ramirez. Norte de Chile. Chungara, 18, 7-13.

Rivera, M. (1991). The prehistory of northern Chile: A synthesis. Journal of World Prehist, 5, 1-47.

Rostworowsky, M. (1981). Recursos naturales renovables y pesca. Siglo XVI y XVII. Lima: Instituto de Estudios Peruanos.

Rostworowsky, M. (1986). La region del Colesuyu. Chungara, 16-17, 127-135.

Rothhammer, F., Cocilovo, J. A., \& Quevedo, S. (1984). El poblamiento temprano de Sudamérica. Chungara, 13, 99-108.

Rothhammer, F., Cocilovo, J. A., Quevedo, S., \& Llop, E. (1982). Microevolution in prehistoric Andean populations: I. Chronologic craniometric variation. American Journal of Physical Anthropology, 58, 391-396.

Rothhammer, F., Cocilovo, J. A., Quevedo, S., \& Llop, E. (1983). Afinidad biológica de las poblaciones prehistóricas del litoral ariqueño con grupos costeros y altiplánicos. Chungara, 11, 161-165.

Rothhammer, F., Quevedo, S., Cocilovo, J. A., Focacci, G., \& Llop, E. (1981). Microevolución en poblaciones prehistóricas del area andina. 2. Variación craneométrica cronológica en los Valles de Arica. Chungara, 8, 275-289.

Rothhammer, F., \& Silva, C. (1989). Peopling of Andean South America. American Journal of Physical Anthropology, 78, 403-410.

Schiappacasse, V., \& Niemeyer, H. (1989). Avances y sugerencias para el conocimiento de la prehistoria tardía en la desembocadura del Valle de Camarones. Chungara, 22, 63-84.
Seber, A. F. (1984). Multivariate observation. New York: Wiley. Standen, V. G. (1991). El cementerio Morro 1: Nuevas evidencias de la tradición funeraria Chinchorro (Período Arcaico, norte de Chile). MSc Thesis. Lima: Universidad Católica de Lima.

Uribe, M. (1995). Cerámicas arqueológicas de Arica (Extremo norte de Chile): Primera etapa de una revaluación tipológica. In Actas del XII Congreso Nacional de Arqueología Chilena, Hombre y Desierto 9 (TII) (pp. 81-96). Antofagasta.

Uribe, M. (1999). La cerámica de Arica 40 años después de Dauelsberg. Chungara, 31, 189-228.

Uribe, M. (2004). De la colección al poder: reflexiones en torno al impacto Tiwanaku sobre la cerámica de Arica (Extremo norte de Chile). Boletín de la Sociedad Chilena de Arqueología, 37, 25-35.

Uribe, M., \& Agüero, C. (2001). Alfarería, Textiles y la integración del Norte Grande de Chile a Tiwanaku. Boletín de Arqueología PUCP, Perú, 5, 397-426.

Varela, H. H., \& Cocilovo, J. A. (2011). Divergencia fenotípica en los Oasis de San Pedro de Atacama, Norte de Chile. Estudios Atacameños, 4, 101-112.

Varela, H. H., \& Cocilovo, J. A. (2002). Genetic drift and gene flow in a prehistoric population of the azapa valley and coast, Chile. American Journal of Physical Anthropology, 118, 259-267.

Varela, H. H., Cocilovo, J. A., Baffi, E. I., \& Valdano, S. G. (1999). La población antigua de la Quebrada de Humahuaca y sus relaciones biológicas con áreas aledañas. Rev Esp Antropological Biology, 20, 7-24.

Varela, H. H., Cocilovo, J. A., Quevedo, S., \& Costa, M. A. (2004a). La Estructura de la Población de Pescadores del Período Arcaico Tardío y Formativo de Arica. Bol Mus Nac Hist Nat, 53, 149-160.

Varela, H. H., Cocilovo, J. A., Santoro, C., \& Rothhammer, F. (2006). Microevolution of human archaic groups of Arica, northern Chile, and its genetic contribution to populations from the Formative Period. Revista Chilena de Historia Natural, 79, 185-193.

Varela, H. H., O’Brien, T. G., \& Cocilovo, J. A. (2008). The genetic divergence of prehistoric populations of the South-central Andes as established by means of craniometric traits. American Journal of Physical Anthropology, 137, 274-282.

Varela, H. H., Paschetta, C. A., \& Cocilovo, J. A. (2004b). Las relaciones biológicas entre subáreas del N.O. argentino establecidas en base al análisis de caracteres métricos. Relaciones, 29, 317-330.

Vera, S. (1981). Momias Chinchorro de preparación complicada del Museo de Historia Natural de Valparaíso: 3290 y 3060 a.C. An Mus Hist Nat Valparaiso, 14, 5-17. 